\title{
North Africa in the Tourist Guidebooks of the 19th and Early 2oth Centuries
}

\author{
Adel Manai \\ PhD, Associate Professor of Modern History, \\ Department of Humanities, Qatar University, \\ University Street, Doha, Qatar
}

Doi: 10.36941/mjss-2020-0030

\begin{abstract}
By the dawn of the twentieth century, a guidebook was a vital element of a tourist's packing list and an item, which a tourist could not do without. The guidebook not only provided practical and useful information, but also advised the tourist about what 'ought to be seen'. It accompanied the development and maturation of modern tourism and witnessed an explosion in the second half of the $19^{\text {th }}$ century and after. The guidebook was gradually improved, highly commercialized, popularized, and extended to many parts of the world and somehow managed to impose 'beaten tracks' on tourists. Similarly, the guidebook accompanied European colonial schemes, served as a tool for them and reflected their agendas and the mindset of the age. This paper is based on a large number of French and English guidebooks spanning approximately the period between the mid-nineteenth and early twentieth centuries and addresses the following questions: when and how was North Africa included in the tourist guidebook literature? What visions did the guidebook provide of the region? How far did the guidebooks contribute to placing North Africa in the global tourist networks and with what effect?
\end{abstract}

Keywords: guidebooks, North Africa, tourism, imperialism, nationalism, progress

\section{Introduction}

Modern tourism, which started to develop in Europe and the United States of America in the second half of the nineteenth century, began to effectively affect North Africa in the last quarter of the century and after. Colonialism played a vital role in bringing tourism to the region. Algeria, Tunisia and not much later, Morocco soon joined chief European tourist destinations (Manai, 2018) as popular attractions for a growing number of tourists from an ever-growing number of European and other countries.

Guidebooks were certainly major markers of the growth of tourism in the $19^{\text {th }}$ century and early nineteenth centuries. Scholars of the history of tourism and tourism studies clearly demonstrated the extent to which guidebooks contributed to the development of the tourist industry (Zuelow, 2016; Perkins, 2007; Allen, 1996; Koshar, 1998; Tissot, 1995; Sillitoe, 1995; Mackenzie, 2005; Maczak, Hastaoglou-Martidinis, 2003 and others). The first guidebooks published by the pioneering publishers, John Murray of London and Karl Baedeker of Coblenz, who started to publish guidebooks for European tourists in the 1830 s, were of major use to the expanding and thriving cultured middle classes, who must have been their main readers then. (Sillitoe, 1995) Soon, the first package tour organisers followed suit. Thomas Cook and Henry Gaze launched their first guidebooks and joined the frenzy by the mid-century. More and diverse guides appeared over time, as the demand for these 
increased and tastes diversified. (Zuelow, 2016) They were essential for tourists, whether these travelled on their own or came as part of an organised journey as most of them increasingly did towards the late nineteenth century. Guidebooks made life easier for them. They were practical, useful and provided up-to-date information on travelling, schedules, transportation, business activities and a whole range of services and products useful to tourists There appeared guides for mountain climbing, for religious shrines and for an ever-increasing number of Non-European countries.

The guidebooks, which first appeared in the nineteenth century, emerged at the phase between the romantic journey and the advent of mass tourism and, were primarily written for the wealthy middle-class travellers, since a journey outside Europe or the United States was far beyond the means of an average household. Over time, the content, form and aim of the guidebooks changed. The guidebook managed to free itself from the influence of the travel narrative and the largely literary and sophisticated outlook it used to have. Guidebooks were progressively aimed at a larger but select public, with cultured interests and searching for comfort and yearning for exoticism not available at home. They started to instruct potential travellers on how to perceive and how to behave in the exotic land they would visit, appeased the uneasiness vis-à-vis the unknown and reassured them of the superiority of their own civilization (Hastaoglou-Martinidis, 2003). Guidebooks were, however, biased and helped shape national identities and defining self and other. "It is perhaps tempting to see them, John Mackenzie (2005) wrote, "as the ephemeral help-mates of the jaded and arrogant imperial traveler". They reflected nineteenth-century European racial and imperialist attitude. Colonial outlooks were in fact on virtually every page (Zuelow, 2016). The connection between tourism and imperialism was evident in an 'age of imperialism', that of the $19^{\text {th }}$ century. Colonialism and empire worked indeed as vehicles along which tourism could grow and expand. They provided favours, patronage and protection for the entrepreneurs of tourism and the tourists as well. The guidebook was used as an instrument of imperial rule and a celebration of the nation-state. It charted progress and the development of the process of imperial modernization and acted as an engine of propaganda for the colonizer. "The French protectorate in Tunis," Thomas Cook wrote in his 1903 edition of his Cook's Practical Guide to Algiers, Algeria and Tunisia," has been most successful, and the country is better governed and more contented than any other of the French possessions... the consequence is that Tunis has prospered steadily since France assumed the protectorate." Walid Hazbun examined the touristic element of European colonialism in British Egypt by Thomas Cook, the famous travel agent, who involved not only the extension of commercial tour operators beyond Europe, but also a new business model suited to colonial tourism (2007). In the same vein, Kenneth Perkin (2007) moved beyond the familiar narrative of commodification of the oriental exotic, focusing in his works on the link between this tourism to the wider French colonial project, as it faced growing threats in the early twentieth century. Guidebooks showed the ongoing progression of modernity and expansion and the spread of the steam technology, the telegraph, sanitation, urbanism, western science and medicine, in short, it displayed the mindset of the era, that of industrial bourgeois progress in an age of progress. The guidebook, itself a product of print capitalism, developed its relationships with colonial enterprise by advertising their products and services. In the same manner, the guidebook reassured the tourist that he/she will be in an environment very similar to the one he/she was familiar with: secure, comfortable and cozy, yet different.

A close analysis of the guidebooks shows how they oscillated between showing the extent to which the colonial states modernized and transformed the tourist sites and the extent to which these sites, in spite of the changes, remained oriental, exotic and worth visiting. In so doing, the guidebook insisted on the capacity of the colonial states to tame and domesticate the native environment. Both worlds, the colonial and the native, were juxtaposed for the tourist to see and admire the achievements of the colonial state.

The first guidebooks to North Africa were released in the 1870 s by the two chief rival publishing houses: John Murray and Karl Baedeker. During the same decade, Louis Piesse started the Guides Joanne Series with Hachette publisher, later renamed Guides Bleus. All these guides were about 
Algeria and Tunisia. Morocco would not have a real share in this guidebook literature before the turn of the century. The publication of guidebooks went hand in hand with the colonial projects and the presence of sizeable European communities in the colonies particularly in the case of Algeria and Tunisia.

The guidebooks consulted in this paper changed over the period under cover. Their language became less academic and their descriptions shorter, more concise and codified. In his handbooks, Thomas Cook used bold to guide tourists to the most important information. The lengthy accounts of the history of Algeria, Tunisia and Morocco, which characterized the early guidebooks, were replaced by brief narratives of the key historical phases of the country. Murray's 1878 Handbook for Travellers in Algeria and Tunis treated Algeria and Tunisia's histories as one and devoted one small section to it. Apart from some differences pertaining to the respective national readership, the guidebooks on North Africa had an almost standardized and organized thematic content that was constructed in a similar and common way since the first editions were launched. They included several sections: one comprising general information and recommendations to the tourist concerning the journey, the itinerary, the budget, the means of transport, currency, postal services, hotels, churches, the Muslim calendar, and all the information deemed necessary for a tourist in a foreign country. A second section described the country's geography, major divisions, locations, climate, natural sites, minerals, flora and fauna, districts, administrative and other buildings and monuments, souks etc. Another section is devoted to the local population, manners and customs, crafts and art, everyday life entertainment and so on. These sections could vary in length, depth and organization offering tourists more accurate and much required information such as indexes with a translation of key local words in Arabic. Successive editions included recent developments and updated their information on tourist accommodation or changes worth mentioning. Information was tested on the spot by the editors themselves or with the contribution of professionals and connoisseurs. In the preface of the third edition of his 1887 Handbook for Travellers, Lambert Playfair recorded his obligation to his friend, Mr. Alexander Graham, Fellow of the Royal Institute of British Architects, a learned Archaeologist and author of Travels in Tunisia with H.S. Ashbee (1887), for much valuable assistance, especially in regard to places in Tunis which his own time would not permit to visit. In the same vein, Thomas Cook made a similar acknowledgment, not only to ancient and modern authors, but also to those people who allowed him to use their photographs such as M. Geiser, MM Volkenweder and Borge, of Algiers and M. Garringues of Tunis (1913).

Over time, also, guidebooks became more professional and increasingly aimed at a tourist population: information was re-organised in such a way as to draw the attention of the guidebook user; more illustrations were used and fewer advertisements were displayed. Thomas Cook and son, now well established and internationally reputed, used his guidebooks to advertise his business. His guidebooks informed his clients about his offices in Algiers and Tunis and focused on the whole range of trips he organized in these countries. The sections on Tunis and Tangiers, which in the early guidebooks, did not exceed a few pages at the end of the guidebook, were increasingly extended over time and updated with more information on other parts of Tunisia and Morocco until both countries had their own guidebooks published.

\section{Algeria, the Instigator}

By the mid-nineteenth century, the French were well settled in Algeria, the chief French colony. An 1848 law incorporating Algeria's three departments into France, implied that French citizens could now visit Algeria as a domestic destination. The first guidebooks on Algeria dated back to 1836 . They accompanied Algerian tourism in its early development with the presence of a large English community living in Algiers, which played a vital role in popularizing Algeria and the whole of North Africa as potential winter resorts. The Guide Quetin published in 1844 was most probably the first guidebook on Algeria. It was aimed at tourists, French above all, but also at those French citizens who might think about settling in Algeria (Zytnicki, 2016). That was above all one of the major 
policies of the French as soon as they colonized Algeria in 1830: encouraging French settlement. French tourists were increasingly viewed as prospective potential settlers, suggesting that the line between tourism and settlement was thin even though the recreational element in these early guidebooks and others was apparent. Tourism and colonialism clearly intersected.

The famous Murray guidebooks appeared in Europe in 1836. Algeria and Tunisia would not have their Murray's before the late 1870 . John Murray's Handbook for Algeria first published in 1876 and Thomas Cook's Practical Guide to Algeria and Tunisia (1903) highly contributed to the incorporation of Algeria in the tourist Mediterranean networks. A second edition of John Murray's guide appeared in 1880 and a third one seven years later under the title of Handbook for Travellers in Algeria and Tunis, Algiers, Oran, Constantine, Carthage etc. This edition was the work of R. Lambert Playfair, author of Handbook to the Mediterranean (1890) and other well-known travel accounts. He was the British Consul-General in Algiers in 1867 , with a thorough knowledge of the region. Both guides treated Algeria and Tunisia as part of the same itinerary, but Algeria had the lion's share of information and advertisement in both guidebooks. Murray's 1878 Handbook edition, for example, devoted 301 pages to Algeria and only 19 pages to Tunisia, limited to Tunis, the capital and its environs. A visit to Tunis would remain a supplement to the journey to Algeria until the very late nineteenth century. Cook's guidebooks, on the other hand, were more informative. That was the main aim of the guidebook spelled out in a long preface. "The purport of the book," Cook writes," is to inform the traveler how to reach Algeria ... and where to go when he gets there. Concise information is afforded as to the most popular districts and principal places of interest, and the book is printed in clear, legible type, with the important places marked, so as to readily arrest the eye." (Cook, 1903) Differently from Murray's guidebook, Cook's had many illustrations and a handy long list of local Arabic words and expressions translated in English for the tourist's use, which would distinguish Cook's guidebooks, even though over time, other guidebooks did the same. These first English guidebooks were another novelty that stimulated the growth of Algerian tourism. They made information accessible to a broader English-speaking public and thus helped diversify the tourist public, especially the British, who used to have a long tradition of travelling and whose contribution to the making of both guidebooks was significant. The English community in Algiers, the first to discover Algiers as a winter resort, played a central role in popularizing tourism in the region and stimulating the proliferation of a guidebook literature. Algeria soon became popular among American tourists, whose numbers increased over time. These largely relied on these guidebooks. Other guidebooks like Harris's The Practical Guide to Algiers (1895), devoted exclusively to Algiers, offered tourists accurate descriptions combined with the briefest and cheapest ways of travelling. The Guide Joanne, the first edition of which was published in 1862, remained one of the traveller's bestliked companions. Adelphe Joanne was employed by Louis Hachette, the famous French publisher in 1852 for the purpose of designing the first collection of tourist guidebooks in France inspired by the German karl Baedecker' tourist guidebookss. The French guidebook was more advertising than touristic. In 1874, the first Guides-Joannes Collection was published under the title Itineraire Historique et Descriptif de l'ALGERIE, de Tunis et de Tanger, by Louis Piesse. As the title suggests, (Algeria in capital letters), this guidebook was above all about Algeria, "les Indes de la France" (India's France) as Piesse depicted it in the guidebook preface with barely a few pages left to Tunis and Tangier. This historical and descriptive itinerary of Algeria was certainly an 'imperial guide', in which Piesse tried to show tourists, French in the first place, the workings of colonial France, 'the evidence of progress, that defining bourgeois philosophy of the age." (Mackenzie, 2005) In 1920, a Joanna Guide of Algiers and Its Environs was published and witnessed a great success since nine editions appeared between 1896 and 1916. By then, tourism in Algeria progressed to the extent that Algiers, the capital had its own guidebook. The early twentieth century was a crucial period for the development of Algerian tourism. Guidebooks, together with the increasingly sophisticated brochures of the Syndicats d'initiative motivated that development. There were, of course, many other guidebooks like the Guide du Touring Club de France (1902), the Guide Pratique Conty (1904) and the Guide Dunlop sur le Tourisme Automobile en Algerie et Tunisie (1923). All of these contributed, in a variety of ways, to 
placing Algeria in increasingly broader tourist networks.

\section{Tunisia Followed Suit}

Travel accounts played a core role in making Tunisia known for many travellers long before the major guidebooks on North Africa were published in the last quarter of the nineteenth century. Some of these guidebooks looked very much like the travel narratives published on Tunisia until then in terms of content and even form sometimes. Many of these guidebooks were inspired by those travel narratives. In his 1903 edition of the Practical Guide to Algiers, Algeria and Tunisia, Thomas Cook acknowledged his obligations to the authors of major travel narratives such as Sir Lambert Playfair, Pere Delattre, V, Guerin, Dr. Thomas Shaw, G. Charmes, M. Gauckler and Sir. H. Johnston, who provided key information to the guidebook publishers later. Guidebooks were certainly crucial for the gradual development of tourism in Tunisia. The French published their own guidebooks. Edouard Gasselin published the Petit Guide de L'étranger à Tunis in 1861 and a second edition eight years later. Gasselin was a drogman at the French General Consulate in Tunis. His seventy-one page, two-piastre guide was a short, pocket-like, rough guidebook dedicated to the infamous Tunisian Prime Minister Mustapha Khaznadar, who was also a leisure entrepreneur and, who most probably sponsored the guide. The guidebook aimed at supplementing what the author considered authoritative guidebooks with a list of useful French vocabulary translated into Tunisian dialect, the prices of posting services, adverts of new French restaurants and grocery shops in Tunis. It is interesting to note that Gasselin's guide was one of the first guides to use to term 'tourist' at a time when the line between travellers and tourists was still vague.

Yet, it was thanks to Lambert Playfair's Handbook for Algeria first published in 1876 and Thomas Cook's Practical Guide to Algeria and Tunisia (1908) that Tunisia was incorporated in the Mediterranean tourist networks. A second edition of Playfair's guidebook appeared in 1880 and a third one seven years later under the title of Handbook for Travellers in Algeria and Tunis, Algiers, Oran, Constantine, Carthage etc. Playfair was, in addition to Algeria, in charge of the consulate of Tunis since 1885 and quite familiar with the country. Both guides treated Algeria and Tunisia as one and as part of the same itinerary, even though Algeria had a greater share of advertisement in both guidebooks. Cook's guidebook was more detailed, especially with regard to the various trips Cook used to organize for his customers. Differently from Playfair's guidebook, Cook added many illustrations and a handy long list of local Arabic words and expressions translated in English for the tourist's use. These English guidebooks significantly contributed to the making of Tunisia as a tourist destination and reinforced the English-speaking tourist clientele in the country. Most guides referred to the well-known travel narratives of Thomas Shaw, Alexander Graham, Edward Rae, Thomas Maggill, Lambert Playfair and others (Manai 2007). Both guides depicted Tunisia as having the proper conditions of a typical winter health resort with diverse attractions (Playfair 1878), hence they contributed to its popularization as a tourist destination. From the eighteenth century onwards, seasonal trips to regions with mild winters was already a well-established cultural and medical tradition in Britain - for the few with means and time. By the late nineteenth century, the thought that Tunis would evolve into a popular winter health resort was widespread. One of the guidebooks with a notable impact on the future of tourism in Tunisia was the Livret-Guide du Comité d'Hivernage de Tunis et de la Tunisie launched in 1903 and freely distributed. The Guidebook "met gratuitement a la disposition des Etrangers tous les renseignements qui peuvent leur etre utiles sur Tunis (fournisseurs, logements, villas) dans les environs de Tunis et dans les stations climatriques (voitures, monuments, resources diverses) et sur les excursions en Tunisie (itineraires, moyen de transport, hotels, guide." (1906) Because it enjoyed the tutelage and support of the Tunisian ruler and the French Resident General, Stephen Pichon, this guidebook became one of the most popular tourist guidebooks in early twentieth-century Tunisia. It was also thanks to the active role of the Comité d'Hivernage de Tunis et de la Tunisie, that this guidebook became a major reference for tourists. 


\section{Morocco and Hachette}

After the fall of Tunisia to French control in 1881, Morocco was the sole exception to colonial rule in North Africa. The French Moroccan protectorate was established only in 1912 and the total pacification of the country was not achieved before 1934. This suggests that the development of tourism in Morocco followed the progress of colonial rule and the total pacification of all the regions. "L'histoire du tourisme au Maroc pendant le protectorat," Boumeggouti and Valero wrote," est tres fortement marque par la nature de cette administration, de son organization et des peripeties de sa mise en place." (Khazdagli, 2009) Before the French conquest of Morocco, the local economy was almost self-contained with little exchange with the outside world. Those who used to visit Morocco were still a minority of privileged European travelers or those seeking adventure. The first mention of Morocco was in Harper's Handbook for Travelers in Europe and the East by Fetridge Pembroke first published in 1862 and 1865. In the section on Spain, Harper suggested a short visit to Tangier from Gibraltar, 40 miles away, into the dominions of the Emperor of Morocco "to get a peep at the finelooking Moors, the former occupants of the Spanish Peninsula." (Harper, 1865). Apart from the natives, however, Harper, did not celebrate Tangier, he thought it was a "dirty and filthy town'. (Harper, 1865) Yet, Tangier would remain the only town present in other guidebooks before the advent of the French protectorate, this time, in Louis Piesse's Collection des Guides-Joanne entitled Itineraire Historique et Descriptif de l'Algerie, de Tunis et de Tanger, published in 1874. Though Tangier would only be allotted five pages in the fifth and last section of the guidebook, Piesse provided the traveller with basic information regarding its history, population, and the main economic activities and introduced the town as the chief seat of all the European consulates as well as the residence of the country's Pasha. In Hyam's Illustrated Guide to Algiers and Algeria (together with a chapter on Morocco (1913), Morocco was allotted two pages only, not a chapter as the title suggested. In these couple of pages, Hyam proposed to the travelers a visit to Oujda, a strategic port taken by the French and the Figuig villages with their oases and 300,00o date palms. (Hyam, 1913) In 1908, Thomas Cook did not do better, since he allocated one page (400-401) only to Morocco in his Cook's Practical Guide to Algiers and Tunisia (1908). Most of the information the guide provided had to do with the regular services Cook provided for those who wished to visit Tangier from Gibraltar and the facilities Cook's agency provided for its British travellers in terms of the excursions organized, the Brighton Hotel with which Cook had a partnership, and its famous coupons.

Not prior to 1919 did Moroccan tourism start to witness a true change. In that year, Hachette, the famous French publisher, issued the first edition of Le Maroc, (Morocco) as part of its popular Guide Bleu series. By then, the series was well established within the tourist industry, especially after many years of publishing guides in French to various destinations such as Greece, Belgium, Luxembourg, Egypt and others. When the first edition of the Guides Bleus Le Maroc was published in 1919, it was one of few tour guides for Morocco and arguably, the most complete. The guide offered its readers detailed information on infrastructures, amenities, historical facts, and places to shop and acquire provisions. The guide was also easy to use (Hunter, 2009). This edition would be followed by four successive editions, in 1921, 1925, 1930, 1936, and later in 1948. This was a clear indicator that the guide was popular. These years, in fact, spanned the progress of Moroccan tourism. Marcel Monmarche, director of the series then, insisted on the necessity for the publication of an up-dated guidebook since Moroccan tourism would experience a vital change in the period under cover. Hachette called on Prosper Ricard (1874-1952), director of the department of native arts in Morocco to author the first full guidebook on Morocco. Ricard was a connoisseur of the region, an architect and spoke Arabic. He began his scholarly career in North Africa in 1900 teaching the local populations of Algeria. During this period, Ricard established himself as an expert on the Muslim arts of the French colonies of North Africa by publishing books and essays. (McLaren, 2006). But most importantly, Ricard worked for the French Protectorate government and enjoyed the full support of the French general resident, Marechal Lyautey. It is not striking, therefore, that the guidebook celebrated Lyautey as the "createur du tourisme au Maroc" and starts with his personal dedication 
which read, “C'est une chance appreciable pour un pays destine a un tel avenir touristique que l'edition d'un "guide bleu du Maroc" et je suis heureux d'en exprimer toute ma gratitude (Ricard, 1919). Prosper Ricard would author the guidebook until the end of the French protectorate and was given full freedom to tour the country and collect information for his guidebook. In addition, Ricard's guidebook enjoyed the official patronage of three heavyweight French tourist institutions, the Touring Club de France, The Office National du Tourisme and the Club Alpin Francais (Ricard, 1919).

The tourist guidebook literature on Morocco in the early twentieth century followed the pace of the French conquest of the country. As the conquest progressed, the Guide Bleu for Morocco included newly conquered regions in the guidebook. By 1936, the guidebook swelled from its original 332 pages to 465 pages, including an extensive bibliography. (Hunter, 2009) A whole range of guidebooks appeared during this period (1920s and 1930s) thus contributing to the development of tourism in Morocco and its popularization as a tourist destination. These included, the Guide Michelin: Maroc (1922), the Guide de la Federation des Syndicats d'Initiative (1928), the Atlas Marocain: Circuit des Casbahs $\mathcal{E}$ des Palmeraies (no date available), the Guides Thiolier (1924), Le Maroc (1932), the Guide General du Maroc (1934), Marrakech et le Grand-Atlas (1935) and Le Maroc du Nord au Sud (1938). The proliferation of tourist guidebooks will continue after World War II. The Guide Bleu, together with the other guidebooks, primarily targeted tourists coming for short periods in autumn and spring as well as French residents in Morocco. The Moroccan summer was still considered too hot for Europeans and other tourists. There was something for everyone in these guidebooks, the short traveller, the French resident, the business seeker, the opportunity seeker, the adventurer, the artist, the historian and geographer and the pleasure seeker. Hachette's guidebooks and the like certainly contributed to generate a greater interest in Morocco and promoted the image of a country, which was progressing and capable of providing a safe and increasingly comfortable and enjoyable stay for tourists, and at the same time a country, which still preserved a great part of its traditional and oriental character.

\section{Conclusion}

The English and French guidebooks, which covered North Africa from the early nineteenth century until, roughly speaking, the late 1930s, were rewarding for the region for one thing: they gradually fitted it in the Mediterranean, then the international tourist networks of the period and supplied it with the basic necessary tourist infrastructure. These assets would be exploited after the independence of these countries and contributed to making tourism one of the major sectors of their economies. What the guidebooks failed to do, was to free themselves from the ideologies of the period. The guidebooks consulted in this paper were fused with colonial discourse, French and other and fully reflected the mindset and culture of the age: nationalistic, stereotyped, and obsessed with progress. Over time, they became more practical, more 'objective' and standardized, but remained somehow imperial even in the post-colonial period.

\section{References}

Allan, E. (1996). "Money and Little red books": Romanticism, Tourism, and the Rise of the Guidebook, LIT, 7, 213226.

Cook, T. (1903). Cook's practical guide to Algiers, Algeria and Tunisia. London: T. Cook \& Son

Cook, T. (1908). Cook's practical guide to Algeria and Tunisia. With maps, plans, and illustrations. London: T. Cook \& Son.

Cook, T. (1913). The Traveller's Handbook for Algeria and Tunisia. London: T. Cook \& son.

Gasselin, E. (1869). Petit guide de l'Etranger à Tunis. Paris: Challamel.

Harris, G. W. (1908) Cook's Practical Guide to Algiers and Tunisia. London: Thomas Cook.

Hastaoglou-Martidinis, V. (2003). Visions of Constantinople/Istanbul from the $19^{\text {th }}$ Century Guidebooks, International Journal of Travel and Travel Writing, 4 (2), 40-57. http://www.ouarzazate-19281956.fr/documents-depoque/bibliographie/275-guides-touristiques-1919-1956.html 
Hazbun, W. (2007). The East as an Exhibit: Thomas Cook \& Son and the Origins of the International Tourism Industry in Egypt. . In Philip Scranton \& Janet F. Davidson (eds), The Business of Tourism: Place, Faith, and History (pp.34.55). Philadelphia: University of Pennsylvania Press.

Hunter, R. F. (2009). Promoting empire: The Hachette tourist in French Morocco, 1919-36, Middle Eastern Studies, 43, (4), 579-591.

Hyam, J. C. (1913). The illustrated guide to Algiers and Algeria: A Practical Handbook for Travellers. Algiers: Hyam and $\mathrm{Co}$.

Hyam, Joseph C. (1908). The illustrated guide to Algiers and Algeria: A Practical Handbook for Travellers. Algiers: Anglo-French Press Association.

Koshar, R. (1998). 'What ought to be seen': Tourists' Guidebooks and National Identities in Modern Germany and Europe, Journal of Contemporary History, 33 (3), 323-340.

La Tunisie: Livret-Guide du Comite d'Hivernage de Tunis et de la Tunisie. Tunis: Societe Anonyme de L'imprimerie papeterie-Rapide, 1906.

Mackenzie, J.M. (2005). Empires of Travel: British Guide Books and Cultural Imperialism in the $19^{\text {th }}$ and $20^{\text {th }}$ Centuries. In J. K. Walton (ed), Histories of Tourism: Representation, Identity and Conflict (pp.19.38).Toronto: Channel View Publications.

MacLaren, B.L. (2006). Architecture and Tourism in Italian Colonial Libya: An Ambivalent Modernism. Seattle and London: University of Washington Press.

Maczak, A. (2003). Gentlemen's Europe: Nineteenth-Century “Handbooks for Travellers, Annali d'Italianistica, 21, 347-362.

Manai, A. (2007). British Travellers in Tunisia: A History of Encounters and representations. Tunis: Centre de Publication Universitaire.

Manai, A. (2018). The origins of Tunisian Tourism, Journal of Mediterranean Studies, 27 (1), 49-61.

Pembroke, F. W. (1865). Harper's Handbook for Travelers in Europe and the East. New York: Harper.

Perkins, J.P. (2007). The Companie Generale Transatlantique and the Development of Saharan Tourism in North Africa. In Philip Scranton \& Janet F. Davidson (eds), The Business of Tourism: Place, Faith, and History (pp.34.55). Philadelphia: University of Pennsylvania Press.

Piesse, L. (1878). Collection des Guides- Joanne: Itineraire Historique de L'ALGERIE, de Tunis et de Tanger. $2^{\text {nd }}$ ed. Paris: Hachette.

Playfair, R. L. (1878). Handbook for Travellers in Algeria and Tunis, Algiers, Oran, Constantine, Carthage, etc. London: J. Murray.

Playfair, R. L. (1887). Handbook for Travellers in Algeria and Tunis, Algiers, Oran, Constantine, Carthage, etc. London: J. Murray.

Playfair, R. L. (1890). Handbook for travellers in Algeria and Tunis: Algiers, Oran, Tlemçen, Bougie, Constantine, Tebessa, Biskra, Tunis, Carthage, etc. London: J. Murray.

Ricard, P. (1919). Le Maroc, Les Guide Bleus, Hachette.

Sillitoe, A. (1995). Leading the Blind: A Century of Guidebook Travel, 1815-1914. London: Macmillan.

Tissot, L. (1995). How did the British conquer Switzerland? Guidebooks, railways, travel agencies, 1850-1914, Journal of Transport History, 16 (1), 22-54.

Zuelow, G.E (2016). A History of Modern Tourism. London: Palgrave Macmillan.

Zytnicki, C (2016). L'Algerie, Terre de Tourisme. Paris: Vendemiaire. Zytnicki, C. \&

Zytnicki, C \& Kazdaghli. H. (eds) (2009). Le Tourisme dans L'empire Français, Politique Pratiques et Imaginaires (XIXe-XXe siècles). Paris: Publications de la Société Française d'Histoire D'outre-mer. 